\title{
STRATEGI PROMOSI SEKOLAH MASTER INDONESIA MELALUI VIDEO PROFIL BERBASIS GRAPHIC ANIMATION
}

\author{
Hesty Gaitsha Heksariani11. Purnomo Ananto² \\ Politeknik Negeri Media Kreatif

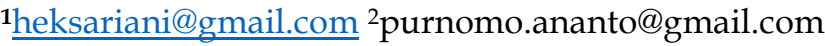

\section{PENDAHULUAN}

Perkembangan teknologi khususnya di bidang informasi dan komunikasi telah berkembang sedemikian pesat terutama pada bidang multimedia.Multimedia merupakan alat yang dapat menciptakan presentasi yang interaktif dan informatif yang mengkombinasikan teks, grafik, animasi, audio, gambar, dan video yang digunakan untuk keunggulan bersaing. Multimedia merupakan salah satu cara yang tepat untuk mempermudah menyampaikan informasi serta mampu menghasilkan sesuatu menjadi lebih komunikatif. Berbagai informasi ditawarkan dalam bentuk multimedia, salah satu penerapannya adalah video profile.

Video profile merupakan salah satu jenis media promosi yang biasa digunakan untuk sebuah perusahaan atau instansi. Video menjadi bentuk media yang baru dalam sebuah presentasi. Tidak bisa dipungkiri juga bahwa kebanyakan orang lebih suka mendengar dan menonton dibandingkan dengan membaca pada saat presentasi. Hal tersebut menjadi kelebihan bagi video profile.

Video profile ini nantinya dapat digunakan diberbagai tempat. Mulai dari melengkapi sebuah presentasi terhadap klien, dapat ditampilkan padalokasi perusahaan atau instansi yang dimiliki, hingga diunggah ke internet dan berpotensi untuk dilihat oleh khalayak luas semakin besar.

Sebuah video profile memiliki jenisnya masing - masing, selain berupa tampilan video (melalui shooting menggunakan kamera, dimana menggunakan objek yang nyata, seperti benda, manusia, dan lainnya), video profile dapat dikombinasikan atau dibuat full dengan melibatkan animasi 2D atau 3D sehingga hasil akhirnya pun akan terlihat lebih menarik. Semua bergantung pada konsep yang diciptakan untuk mewakili apa yang ditawarkan atau ingin disampaikan kepada konsumen maupun masyarakat luas.

Penggunaan video profile sendiri sebenarnya sudah dianggap penting dan menjadi kebutuhan mutlak sebagai sarana promosi dan media komunikasi paling efektif. Memiliki fungsi sebagai alat marketing, maka video profile mampu memberikan pemahaman atas apa yang perusahaan atau instansi tersebut miliki selama ini.

Adalah Sekolah Master Indonesia, merupakan salah satu lembaga pendidikan gratis yang berada di wilayah Depok, tepatnya di samping 
terminal Depok. Berdiri dibawah naungan Yayasan Bina Insan Mandiri (YABIM), sekolah ini dikhususkan bagi anak-anak dhuafa serta kaum marjinal yang berada disekitar wilayah terminal Depok. Untuk sebagian operasionalnya, Sekolah Master disupport oleh Lembaga lembaga peduli pendidikan, partisipasi dari masyarakat, pemerintah, relawan - relawan yang dominan dari kalangan pelajar dan mahasiswa, serta unit usaha mandiri dari Sekolah Master.

Terpublikasinya Sekolah Master sejauh ini hanya melalui mulut ke mulut, juga melalui beberapa stasiun televisi yang meliput Sekolah Master, itupun dikarenakan prinsip yang Sekolah Master miliki yaitu memberikan pendidikan yang benar benar gratis bagi golongan menengah ke bawah patut diapresiasi. Selain dari itu semua, hingga saat ini Sekolah Master belum memiliki media informasi dan promosi untuk memperkenalkan keseluruhan tentang Sekolah Master Indonesia, seperti sejarah berdirinya Sekolah Master, visi dan misi, fasilitas, program pendidikan, dan hal lainnya. Hal ini sangat disayangkan, mengingat tujuan mulia didirikannya Sekolah Master adalah untuk memberikan pendidikan gratis bagi kaum marjinal, sudah selayaknya semua orang mengetahui lebih banyak tentang Sekolah Master ini.

Sekolah Master memiliki website dengan domain yang masih gratis yaitu wordpress dan sosial media dalam menyampaikan media informasi dan promosi, namun hal tersebut dirasa masih kurang dalam memperkenalkan Sekolah Master, karena website yang dibuat belum begitu maksimal navigasinya dan sosial media tidak cukup untuk menginformasikan tentang Sekolah Master secara visual. Media informasi dan promosi yang Sekolah Master miliki masih berupa tulisan dan gambar, sehingga terlihat kurang menarik, interaktif, dan atraktif. Sedangkan pada umumnya masyarakat lebih mudah menerima informasi melalui media yang interaktif dan komunikatif.

Menciptakan media video profile yang menarik mengenai Sekolah Master sehingga dapat membantu program - program Sekolah Mater yang lebih efektif.

Videoprofil adalah media berupa tampilan audio visual yang digunakan untuk mengenalkan, menginformasikan dan mempromosikan suatu instansi, lembaga, atau perusahaan dengan tampilanyang lebih menarik kepada khalayak luas.

Menurut (Wawan Kuswandi: Sebuah analisis si media, 2011, hlm: 47), Videoprofiladalah sebuah gambaran informasi tentang riwayat seseorang atau sebuah instansi perusahaan yang telah mencapai suatu pencapaiankesuksesan dalam hal produksi atau hasil karya yang telah dihasilkan dan diterima di kalanganmasyarakat umum. Informasi 
tersebut disebarkan berbentuk audio visual atau video.

Menurut (Fred Wibowo: Teknik Produksi Program Televisi, 2007, hlm: 34 - 36), Videoprofilmerupakan video yang diproduksi untuk keperluan tertentu, misalnya memperkenalkan suatuperusahaan tertentu untuk disebarluaskan ke publik, selain itu sering dipakai sebagai sarana pendukung dalam suatu presentasi perusahaan atau kelompok tertentu.

Lembaga yang terkait dalam penelitian ini adalah Sekolah Master Indonesia (Master merupakan akronim dari Masjid Terminal) yang merupakan Sekolah Gratis dan diperuntukkan untuk golongan menengah kebawah (Kaum Marjinal).

Guna mendapatkan legalitas perijinan mendirikan bangunan sekolah, maka Sekolah Master Indonesia berdiri di bawah naungan Yayasan Bina Insan Mandiri (YABIM) pada hari Sumpah Pemuda tahun 2000. Sebagian operasional yang ada pada Sekolah Master Indonesia disupport oleh lembaga - lembaga peduli pendidikan, partisipasi masyarakat, pemerintah, dan unit usaha mandiri yang Sekolah Master miliki.

Sekolah yang terletak di Jl. Margonda Raya No: 58, Terminal Terpadu Depok ini, dalam masa perkembangannya 3 tahun belakangan telah memiliki TK, SD, SMP dan SMA yang layak dan siap bersaing dengan lembaga sekolah formal lainnya. Terhitung pada tahun 2015, Sekolah
Master telah memiliki 3500 Siswa/i atau Murid dari golongan kaum marjinal dengan jumlah staf atau guru relawan tetap berjumlah 20 - 30 orang dengan masing - masing divisi yang telah ditetapkan.

Penulis melihat masalah yang timbul yaitu adanya sekolah gratis (Sekolah Master Indonesia) yang diperuntukkan bagi golongan menengah kebawah dimana dengan sekolah tersebut tentunya sangat membantu mengurangi jumlah anak anak yang putus sekolah di Indonesia karena faktor kurang mampu untuk membiayai biaya operasional di sekolah pada umumnya. Akan tetapi, media untuk mempromosikan sekolah gratis tersebut masih kurang, padahal apabila Sekolah Master Indonesia mempunyai sebuah media untuk promosi maka bukan tidak mungkin semakin banyak anak - anak yang terbantu dengan adanya sekolah gratis tersebut.

\section{METODE PENELITIAN}

Salah satu proses penting dalam tahap pembuatan video profil yaitu pengumpulan data yang merupakan sekumpulan informasi berdasarkan fakta yang diperoleh dan kemudian nantinya diproses atau diolah menjadi sesuatu yang dapat dimengerti oleh orang lain. Dengan adanya sebuah data, penulis memiliki patokan dan menjadi tahu apa - apa saja nantinya yang akan ditampilkan pada video profil tersebut. Pengumpulan data yang penulis lakukan yaitu dengan cara mewawancarai staff - staff 
penting dari Sekolah Master Indonesia.

Berdasarkan hasil dari mewawancarai staff - staff yang bersangkutan, penulis mendapatkan data yang diperoleh untuk menunjang pembuatan video profil Sekolah Master Indonesia, seperti sejarah Sekolah Master Indonesia, visi dan misi, program - program yang diadakan, fasilitas, dan beberapa data penunjang lainnya.

Setelah terbentuknya sebuah ide beserta dilengkapi data yang valid. Maka, tahapan dilanjutkan dengan perancangan ide yaitu konsep. Penentuan sebuah konsep tentunya haruslah matang, seperti style animasi yang akan dibuat, karakter, alur cerita, durasi waktu, dan lainnya. Hal ini dimaksudkan agar tidak terjadi penyimpangan pada saat memulai produksi.

\section{HASIL DAN PEMBAHASAN}

Penulis bmembuat konsep video profil dengan menggunakan animasi sederhana, disertai dengan cerita yang menarik seperti sejarah awal pendiri dari Sekolah Master Indonesia terpikirkan untuk membuat sekolah gratis, dilanjutkan dengan perkembangan Sekolah Master Indonesia hingga saat ini dan disertai dengan karakter karakter pendukung yaitu anak - anak kaum marjinal. Untuk target durasi yang penulis tetapkan berkisar antara 1 - 3 menit. Setelah konsep terbentuk dengan matang, penulis melanjutkan dengan mencari referensi animasi ataupun gambar untuk tahap pembuatan video profil.

Menentukan tema pada sebuah video profil adalah langkah selanjutnya. Tema adalah makna yang dikandung oleh sebuah cerita. Tema pada pembuatan sebuah video profil biasanya mengerucut pada satu hal. Disini penulis telah menentukan tema yang juga sudah disepakati oleh Sekolah Master Indonesia, yaitu "Story of Master". Sebelum memasuki tahap storyboard, penulis membuat storyline terlebih dahulu. Storyline adalah naskah kasar berupa teks mengenai detail apa yang nantinya akan ditampilkan dalam bentuk storyboard. Hal ini dapat membantu penulis dalam membayangkan gambaran untuk storyboard.

Setelah storyline dibuat, kemudian tahap selanjutnya adalah storyboard. Wujud dari storyboard adalah sketsa gambar dimana sketsa tersebut dapat memvisualisasikan konsep yang sudah tertulis (storyline). Dengan pembuatan storyboard, penulis menjadi terbantu untuk membuat tampilan tampilan dalam setiap sceneatau adegan yang ada di dalam video profil tersebut.

Pada tahap ini, penulis memulai pembuatan gambar karakter serta ilustrasi yang akan ditampilkan dalam video profil. Karakter maupun ilustrasi yang dibuat berdasarkan data yang telah diperoleh serta storyboardyang telah disusun sebelumnya.Pembuatan karakter dan ilustrasi pada awalnya dibuat dengan 
manual terlebih dahulu menggunakan alat tulis, lalu kemudian di scan atau di buat secara digital dengan menggunakan warna - warna yang menarik, diberikan bayangan serta diperhalus garis gambarnya melalui software Adobe Photoshop dan Adobe Illustrator.

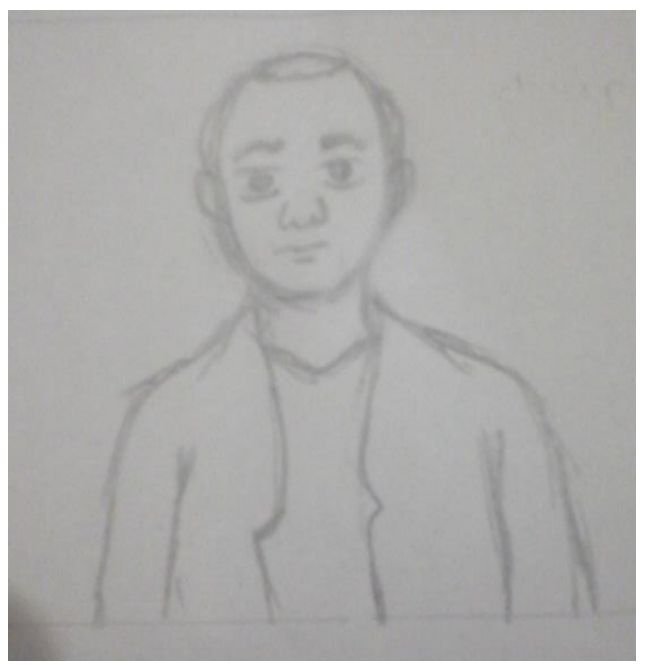

Beberapa karakter yang telah penulis buat untuk mendukung cerita dalam video profil. (Sumber: Karya penulis)

Setelah karakter dan ilustrasi dibuat lebih menarik melalui coloring digital menggunakan software, selanjutnya karakter dan ilustrasi akan memasuki tahap penggerakan animasi agar terlihat lebih komunikatf dan interaktif. Untuk tahap menggerakan animasi, penulis harus memisahkan terlebih dahulu bagian apa saja yang harus dianimasikan dan tidak. Untuk software yang digunakan adalah Adobe Flash dan Adobe After Effects.

Pada tahap ini dilakukan pemilihan atau pencarian musik serta sound effect yang dapat mendukung unsur audio dari video profilSekolah Master Indonesia. Selain itu, musik dan sound effectberguna untuk menambahkan suasana agar tidak menjadi hampa pada video profil tersebut.

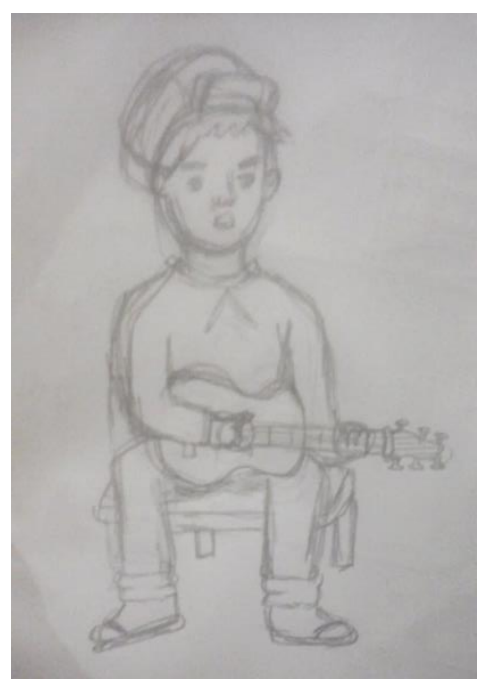

Setelah semua komponen seperti animasi dan musik selesai, maka tahap terakhir ialah editing, yaitu menyatukan semua komponen atau scene yang telah dibuat menjadi satu cerita atau menjadi satu file yang utuh, kemudian dirapihkan serta diperiksa kembali sebelum memasuki tahap rendering. Jika sudah dipastikan tidak ada kesalahan dalam pembuatan video profil yang telah dibuat, maka baiknya video tersebut memasuki tahap rendering. Dalam hal ini, penulis dapat mengetahui output finaldari video animasi yang telah dibuat. Kemudian, video profil pun siap untuk dipromosikan dan disebarluaskan di Internet.

\section{KESIMPULAN}


Video Profil ini pada dasarnya adalah salah satu media informasi dan promosi yang informatif dalam mempublikasikan Sekolah Master Indonesia.Meskipun demikianSeiring perkembangannya Sekolah Master Indonesia, maka video profil yang dibuat tidak bisa dipakai secara terus menerus, harus ada pembaharuan informasi.Video profile ini dapat menjadi tren bagi lembaga pendidikan yang lain untuk menerapkan video profil yang serupa dan berkesempatan untuk mempromosikan Sekolah Master Indonesia lebih besar lagi, sehingga diketahui lebih banyak orang.

\section{DAFTAR PUSTAKA}

Binanto, Iwan. (2010). "Multimedia Digital-Dasar Teori Pengembangannya".Andim Yogyakarta.

Ferusita, Septia . 2016. Buku Tugas Akhir Pembuatan Media Pembelajaran Interaktif Pengenalan Astronomi dan Galaksi Menggunakan Hologram

Hanafi, fahrizal.2015.Buku Tugas Akhir Tutorial Animasi Pembuatan Rumah Berteknologi RISHA menggunakan Vuforia :Jakarta

Hahn, Fred E, dan Mangun, Kenneth J. (2002), "Beriklan dan Berpromosi Sendiri, Edisi Kedua" Grasindo. Jakarta

Hendratman, Hendi .The Magic of 3D
Studio Max Modelling Rendering Animation

Jubilee Enterprise.(2015) "Membuat Company Profile dengan WordPress".Elex Media Komputindo, Jakarta.

Kusrianto, Adi. (2009). "Pengantar Desain Komunikasi Visual, Edisi Kedua".Andi, Yogyakarta.

Pranowo, Galih. 2011. Kreasi animasi interaktif dengan actionscript 3.0 pada flash CS5, Jakarta.

Rustan, Surianto, S.Sn. (2010). "Font \& Tipografi", Gramedia Pustaka Utama, Jakarta

Tjiptono, Fandy. (1997). "Strategi Pemasaran, Edisi Kedua".Andi, Yogyakarta 